The University of Southern Mississippi

The Aquila Digital Community

Faculty Publications

$2-1-2008$

\title{
Effects of Cyclic Hypoxia On Gene Expression and Reproduction In a Grass Shrimp, Palaemonetes pugio
}

\author{
Nancy J. Brown-Peterson \\ University of Southern Mississippi, nancy.brown-peterson@usm.edu \\ C. Steve Manning \\ University of Southern Mississippi \\ Vishal Patel \\ University of Florida \\ Nancy D. Denslow \\ University of Florida \\ Marius Brouwer \\ University of Southern Mississippi
}

Follow this and additional works at: https://aquila.usm.edu/fac_pubs

Part of the Marine Biology Commons

\section{Recommended Citation}

Brown-Peterson, N. J., Manning, C. S., Patel, V., Denslow, N. D., Brouwer, M. (2008). Effects of Cyclic Hypoxia On Gene Expression and Reproduction In a Grass Shrimp, Palaemonetes pugio. Biological Bulletin, 214(1), 6-16.

Available at: https://aquila.usm.edu/fac_pubs/1477

This Article is brought to you for free and open access by The Aquila Digital Community. It has been accepted for inclusion in Faculty Publications by an authorized administrator of The Aquila Digital Community. For more information, please contact Joshua.Cromwell@usm.edu. 


\title{
Effects of Cyclic Hypoxia on Gene Expression and Reproduction in a Grass Shrimp, Palaemonetes pugio
}

\author{
NANCY J. BROWN-PETERSON ${ }^{1}$, C. STEVE MANNING ${ }^{1}$, VISHAL PATEL ${ }^{2, *}$, \\ NANCY D. DENSLOW ${ }^{2}$, AND MARIUS BROUWER ${ }^{1, \dagger}$ \\ ${ }^{1}$ Department of Coastal Sciences, The University of Southern Mississippi, 703 East Beach Dr., Ocean \\ Springs, Mississippi 39564; and ${ }^{2}$ Department of Physiological Sciences and Center for Environmental \\ and Human Toxicology, University of Florida, PO Box 110885, Gainesville, Florida 32611
}

\begin{abstract}
Cyclic changes in dissolved oxygen occur naturally in shallow estuarine systems, yet little is known about the adaptations and responses of estuarine organisms to cyclic hypoxia. Here we examine the responses of Palaemonetes pugio, a species of grass shrimp, to cyclic hypoxia $(1.5-8 \mathrm{mg} / \mathrm{l}$ dissolved oxygen; $4.20-22.42 \mathrm{kPa}$ ) at both the molecular and organismal levels. We measured alterations in gene expression in hepatopancreas tissue of female grass shrimp using custom cDNA macroarrays. After short-term (3-d) exposure to cyclic hypoxia, mitochondrial manganese superoxide dismutase (MnSOD) was upregulated and 70-kd heat shock proteins (HSP70) were downregulated. After 7-d exposure, nuclear genes encoding mitochondrial proteins (ribosomal protein S2, ATP synthase, very-long-chain specific acyl-CoA dehydrogenase [VLCAD]) were downregulated, whereas mitochondrial phosphoenol pyruvate carboxykinase (PEP Cbk) was upregulated. After $14 \mathrm{~d}$, vitellogenin and apolipoprotein A1 were upregulated. Taken together, these changes suggest a shift in metabolism toward gluconeogenesis and lipid export. Long-term (77-d) exposure to hypoxia showed that profiles of gene expression returned to pre-exposure levels. These molecular responses differ markedly from those induced by chronic hypoxia. At the organismal level, cyclic hypoxia reduces the number of
\end{abstract}

Received 7 June 2007; accepted 19 October 2007.

* Present address: Bristol-Myers Squibb, Pennington, NJ 08534.

$\dagger$ To whom correspondence should be addressed. E-mail: marius.brouwer@usm.edu

Abbreviations: DO, dissolved oxygen; $\mathrm{HH}$, continuous exposure to cyclic hypoxia; HN, 2-week exposure to cyclic hypoxia and then exposure to normoxia; NN, continuous exposure to normoxia; PEP Cbk, phosphoenol pyruvate carboxykinase; SAM, significance analysis of microarrays; SOD, superoxide dismutase; VLCAD, very-long-chain specific acyl-CoA dehydrogenase. broods and eggs a female can produce. Demographic analysis showed a lower estimated rate of population growth in grass shrimp exposed to both continuous and short-term cyclic hypoxia, suggesting population-level impacts on grass shrimp.

\section{Introduction}

Increases in the extent, frequency, and severity of hypoxia in coastal and estuarine environments are of concern in relation to declines in habitat quality (Diaz and Rosenberg, 1995; Buzzelli et al., 2002). Although the occurrence of areas of severe hypoxia, often driven by stratification of the water column and fueled by eutrophication, has been well documented along the Atlantic and Gulf coasts of the United States (Turner and Rabalais, 1994; Paerl et al., 1998; Rabalais et al., 2002), less severe episodic hypoxic conditions can occur during the summer in shallow waters due to winds and tides, causing periodic upwelling of hypoxic bottom waters (Sanford et al., 1990, Bell et al., 2003). Additionally, daily cyclic patterns of hypoxia and normoxia can develop in combination with tidal action even in the absence of stratification, as a result of photosynthesis during periods of light and respiration during periods of darkness (Ringwood and Keppler, 2002; Tyler and Target, 2007). Consequently, estuarine and marine organisms are likely to experience hypoxic conditions during at least one phase of their life history. Thus, a better understanding of how these organisms respond to hypoxia from a molecular, physiological, behavioral, or population-level perspective is of considerable biological interest and may also provide crucial information needed to predict the impacts of hypoxia on estuarine ecosystems.

The responses of estuarine and marine fishes and crusta- 
ceans to chronic hypoxia have been well documented and include avoidance or escape behavior (Wannamaker and Rice, 2000; Wu et al., 2002; Craig et al., 2005; Bell and Eggleston, 2005), physiological adaptations for regulating oxygen transport (DeFur et al., 1990; Mangum, 1997; Terwilliger, 1998; McMahon, 2001; Paul et al., 2004), and reduction in growth (McNatt and Rice, 2004; Eby et al., 2005; Stierhoff et al., 2006). Similar responses have been documented for estuarine fishes and invertebrates exposed to cyclic, or intermittent, hypoxia (Nestlerode and Diaz, 1998; Coiro et al., 2000; Bell and Eggleston, 2005; Tyler and Targett, 2007). More recently, differential gene expression in response to chronic hypoxia has been documented in fishes (Gracey et al., 2001; Ton et al., 2002, 2003; van der Meer et al., 2005) and invertebrates (Brouwer et al., 2005, 2007; Brown-Peterson et al., 2005; David et al., 2005).

Although our knowledge of the response of aquatic organisms to chronic hypoxia has steadily increased, surprisingly little is known about the mechanisms of adaptation of estuarine organisms to cyclic hypoxia, which occurs naturally and can be exacerbated by increased nutrient loading. This lack of knowledge prompted us to investigate the effects of cyclic hypoxia on gene expression and reproduction in the hypoxiatolerant grass shrimp Palaemonetes pugio Holthuis, 1949 , as this species has been shown to be uniquely physiologically adapted to stressful tidal marsh habitats (Welsh, 1975). Grass shrimp, which are a key link in the estuarine detritus food chain, have recently been proposed to be a relevant estuarine organism for use as a bioindicator of anthropogenic impacts (Key et al., 2006). We have previously shown that expression levels of $P$. pugio genes that encode proteins involved in oxygen and electron transport, energy, and iron metabolism may be useful molecular indicators of both short-term (3-d) and moderate (14-d) exposure to severe $(1.5 \mathrm{mg} / \mathrm{l} \mathrm{DO}, 4.20$ $\mathrm{kPa}$ ) chronic hypoxia (Brouwer et al., 2007). In addition, we found that chronic hypoxia significantly impacted both fecundity and interbrood interval, which may have population-level impacts on grass shrimp. We hypothesized that grass shrimp exposed to cyclic hypoxia would show different and less dramatic changes in gene expression and reproductive parameters than those exposed to chronic hypoxia, since grass shrimp routinely experience cyclic hypoxia in the wild during their summer reproductive period. To test this hypothesis, we exposed grass shrimp to $77 \mathrm{~d}$ of cyclic hypoxia in the laboratory and evaluated the responses of a suite of reproductive parameters, demographic measurements, and hypoxia-responsive genes. We also compared the differences in gene expression observed in grass shrimp exposed to chronic versus cyclic hypoxia.

\section{Materials and Methods}

\section{Experimental animals and exposure methods}

Dip nets were used to collect individuals of Palaemonetes pugio from Davis Bayou, in the vicinity of Ocean Springs, Mississippi. Adult females and males were segregated by sex on the basis of morphological differences in the first and second pleopods (Meehean, 1936); they were maintained in the laboratory at a practical salinity of 15 and a temperature of $27 \pm 1{ }^{\circ} \mathrm{C}$ for 7 to $30 \mathrm{~d}$ prior to experimentation. During acclimation and experimentation periods, the shrimp were fed brine shrimp nauplii and commercial flake food once daily. During all acclimation and experimentation periods, shrimp were held in artificial seawater (Fritz Super Salt, Fritz Industries, Mesquite, TX) diluted to a salinity of 15 with non-chlorinated well water.

The exposures were conducted in a modified intermittent flow-through system previously described (Manning et al., 1999). The flow-through test system provided 11 of seawater every $20 \mathrm{~min}$ (resulting in three complete volume additions/day) to each of the 35-1 test aquaria; a separate waterdelivery partitioner was used for each of the normoxic and cyclic hypoxic treatments. Oxygen levels were controlled by bubbling nitrogen into a holding tank that gravity-fed to the partitioner used to deliver flow-through hypoxic seawater. Treatment aquaria were additionally adjusted with nitrogen bubbled through the dilution water in the aquaria. Two 24-h timers equipped with 15-min interval switching were used to activate a solenoid valve that controlled nitrogen introduction into the holding tank and the treatment aquaria at predetermined intervals; these intervals had been experimentally determined to maintain the desired oxygen level in the aquaria. One timer controlled introduction of nitrogen flow during the evening, and the second timer controlled addition of oxygen to the holding tank and aquaria during daylight. The normoxic-treatment aquaria were maintained by a separate water partitioner that provided flow-through normoxic seawater by gently bubbling oxygen into the cells of the water partitioner prior to delivery of water to the individual aquaria. Oxygen, temperature, salinity, and $\mathrm{pH}$ were monitored continuously in one cyclic hypoxic flow-through aquarium, and the frequency of addition of nitrogen and oxygen was adjusted as required to maintain the desired oxygen cycle. Dissolved oxygen, temperature, salinity, and $\mathrm{pH}$ were measured in all flow-through aquaria once or twice daily, using a YSI model 600XLM data sonde.

Grass shrimp were housed individually or in reproductive pairs in retention chambers as described previously (Brouwer et al., 2007). Briefly, 25 chambers were placed into 35-1 flow-through glass aquaria in a water bath held at $27 \pm 1$ ${ }^{\circ} \mathrm{C}$. This compartmentalization of the test organisms precluded cannibalism and enabled individual shrimp to be identified and their molts enumerated. 


\section{Reproductive and gene expression sampling}

A 77-d laboratory experiment was conducted to determine the effects of cyclic hypoxia on gene expression and reproduction in grass shrimp. Before being mated for reproductive studies, the shrimp were isolated individually in retention chambers placed in 12 aquaria. Male ( 2 tanks $\times 25$ shrimp) or female (5 tanks $\times 25$ shrimp) shrimp were maintained in seven cyclic-hypoxic aquaria (24-h DO cycle from $1.5 \mathrm{mg} / \mathrm{l}$ to $8 \mathrm{mg} / \mathrm{l} ; 4.20$ to $18.88 \mathrm{kPa} ; 20.5 \%$ to $109 \%$ saturation). The normoxic shrimp $(6-8 \mathrm{mg} / \mathrm{l} \mathrm{DO} ; 16.81-$ $22.42 \mathrm{kPa} ; 82.1 \%-109 \%$ saturation) were housed in one tank of 25 males and four tanks of 25 females. Twenty female shrimp (10 normoxic, 10 cyclic hypoxic) were sampled three times (on days 3, 7, and 14) during the studies for analysis of gene expression. Shrimp were always sampled between 0800 and $1000 \mathrm{~h}$, when DO levels were beginning to increase from the daily low value. At the beginning of the experiment, 10 female shrimp were removed from the test population for the day 0 assessment. At each sampling time, sample selection was from females that had egg masses, and eggs were removed and counted. Shrimp were anesthetized in ice water, and the total length (TL, $\mathrm{mm}$ ) and egg-free wet weight (ww, $0.1 \mathrm{mg}$ ) were recorded for each shrimp. The thorax was removed and stored at $-20{ }^{\circ} \mathrm{C}$ in RNAlater (Ambion, Inc., Austin, TX) for extraction of RNA and analysis of gene expression.

At the end of 2 weeks under cyclic hypoxic or normoxic conditions, males and females were paired, on the basis of hypoxia exposure, into reproductive groups to determine differences in fecundity, interbrood interval, and survival of the F1 generation in multiple broods. All females were weighed at the start of the reproductive study. Hypoxic males were paired with hypoxic females in 25 individual breeding chambers under continued cyclic hypoxic conditions. All other mating pairs (hypoxic male [25] $\times$ hypoxic female [25] and normoxic male [25] $\times$ normoxic female [25]) were kept under normoxic DO. During the study, females with egg masses were isolated into hatching chambers within their aquaria $(5-\mathrm{cm}$ petri dish with a $10-\mathrm{cm}$ collar of 1-mm mesh) 7 to $8 \mathrm{~d}$ after first observation of the eggs. The hatching chamber was placed in a larger retention chamber of smaller mesh $(200 \mu \mathrm{m})$ to retain hatched larvae and separate them from the female. After the eggs hatched, the female was weighed and returned to the original retention chamber with her mate. This method allowed for assessment of multiple broods from each reproductive pair. All hatched larvae were counted, and about 25 larvae from each female were isolated into a $200-\mu \mathrm{m}$-mesh chamber for survival assessment. Normoxic and cyclic hypoxic larvae from each female and each brood were kept under normoxic conditions and monitored twice daily until they died from starvation. Larvae were not fed during this time to determine whether yolk content changed with subsequent broods and whether survival differed between normoxic and cyclic hypoxic broods. The reproductive portion of the experiment was terminated after 9 weeks, and all females were weighed, measured, and sacrificed for gene expression analysis as described above.

\section{Macroarrays}

Gene arrays consisting of 76 genes previously identified as useful in assessing grass shrimp exposure to chronic hypoxia (Brouwer et al., 2007) were used to evaluate gene expression. These genes were divided into 11 functional groups, including protein folding, repair, and translocation (6 genes); protein synthesis (13 genes); protein degradation (7 genes); lipid metabolism (8 genes); ATP synthesis and electron transport ( 7 genes); oxygen transport and sensing (5 genes); carbohydrate metabolism (7 genes); cell structure, motility, and muscle contraction (6 genes); metalbinding and antioxidant properties (5 genes); blood coagulation and immune function (6 genes); and miscellaneous functions (6 genes). Several genes are part of the mitochondrial genome (4), whereas others are nuclear genes that encode mitochondrial proteins (8). All identified genes were amplified by PCR and then robotically spotted in duplicate onto neutral nylon membrane macroarrays together with various controls, including exogenous Arabidopsis "spiking" genes, as previously described (Larkin et al., 2003).

Total hepatopancreatic RNA was extracted from 8-10 female grass shrimp per treatment group using Stat-60 (TelTest, Friendswood, TX). Genomic DNA was removed by DNase treatment, and total RNA was transcribed into radiolabeled cDNA and hybridized to the membranes for each individual shrimp. Background subtraction for each cDNA spot was performed as previously described by Larkin et al. (2003). The values were then $\log _{2}$-transformed and normalized to the median intensity of the array data. Fold-change values, calculated from the ratio of the mean value of normalized cyclic hypoxic to normoxic shrimp for each time point, were used to determine which gene transcripts were increased (upregulated) or decreased (downregulated) by cyclic hypoxia. Gene signal intensities among macroarrays hybridized with the same labeled cDNA have been shown to be highly consistent (slope of regression $=0.955$; $r^{2}=0.9326$ ). Comparison of mean normalized gene intensities of normoxic control shrimp from two experiments ( $n=21$ and $n=33$ ) showed good correlation (slope of regression $=0.887 r^{2}=0.797$ ), indicating that variability of gene expression levels among shrimp is modest. The macroarrays have been previously validated with real-time quantitative PCR using nine strongly expressed genes at multiple time points (Brouwer et al., 2007). 


\section{Data analysis}

Throughout all experiments, each shrimp in its individual chamber is considered a replicate for both gene expression and reproduction $(n=10)$ because maintaining hundreds of shrimp in individual experimental units at the same DO is logistically impossible. Additionally, the flow-through system and high volume of water exchange in each experimental aquarium limited interaction through chemical cues among shrimp in the same aquarium, whereas the separation into individual retention chambers prevented physical interactions. Finally, to approach a true replicate design as much as possible, at each time point shrimp were collected from different aquaria.

Growth of females was assessed by subtracting the weight of the females at the start of the reproductive experiment from the weight of the females after release of each brood and at the end of the experiment. Condition factor $(K)$ was calculated for each female $\left(K=\mathrm{ww} / \mathrm{TL}^{3.74} \times 100,000\right)$ after each brood was hatched and at the end of the study. The intercept of the length-weight regression of pooled, normoxic grass shrimp from multiple experiments $(n=$ 200) was used for the exponent in the condition-factor equation. Relative fecundity of grass shrimp was calculated by dividing the number of hatched larvae by the ww of the female, and is expressed as number of larvae per gram. Reproductive groups were defined on the basis of the DO history of the females: females continuously exposed to cyclic hypoxia $(\mathrm{HH})$, females continuously exposed to normoxia (NN), and females exposed to cyclic hypoxia the first 2 weeks of the study but allowed to mate in normoxia (HN).

Population growth rate $(\lambda)$ was calculated for each reproductive group, following a simple demographic model as outlined by Forbes and Cold (2005):

$$
\lambda=(1 / 2 n * S)^{1 / t}
$$

where $n$ is the mean relative fecundity, $S$ is the mean proportion of embryos that hatched alive, and $t$ is the mean interbrood interval in days. The $95 \%$ confidence intervals for $\lambda$ were calculated on the basis of the $95 \%$ confidence intervals of each of the parameters. If the $95 \%$ confidence limits for $\lambda$ did not overlap, we considered the $\lambda$ values to be significantly different (Forbes and Cold, 2005).

Differences in growth, $K$, relative fecundity, interbrood interval, percentage of hatched embryos, and larval survival among treatment groups were tested using ANOVA; differences among groups were evaluated with the Bonferroni post hoc test. Parameters that occurred in only two treatment groups were evaluated using Student's $t$-test. Percentage data were arcsine-square- root-transformed prior to analysis (Sokal and Rohlf, 1995). Data were tested for homogeneity of variance (Levene's test) and normality of distribution (one-sample Kolmogorov-Smirnoff test) and were logtransformed if necessary to meet these assumptions. Stu- dent's $t$ test and ANOVA were performed with SPSS (ver. 11.5). Data were considered significant if $P \leq 0.05$.

Gene expression data from macroarrays normalized to the array median intensity were analyzed with Student's $t$-test and significance analysis of microarrays (SAM; Tusher $e t$ al., 2001) to determine differences between normoxic and cyclic hypoxic grass shrimp for each time point $(3,7,14$, and $77 \mathrm{~d}$ ). Changes in gene expression were considered significant if they obeyed the following criteria: $P \leq 0.05$ ( $t$-test) and $q<8$ (SAM).

\section{Results}

\section{Survival and growth}

The oxygen controller maintained a consistent DO cycle in the cyclic hypoxia exposure tanks for the 77-d duration of the experiment (Fig. 1). The lowest DO values $(1.14 \pm 0.04$ $\mathrm{mg} / \mathrm{l}$ DO, range 0.49-1.73) occurred between 0600 and 0800 each morning, and the highest DO values $(9.22 \pm 0.14$ $\mathrm{mg} / \mathrm{l}$ DO, range 5.91-18.39) occurred between 1200 and 1800 daily. Grass shrimp were exposed to hypoxic conditions (DO $\leq 2 \mathrm{mg} / \mathrm{l}$ ) for an average of $7.2 \pm 0.6 \mathrm{~h}$ during every 24 -h period throughout the experiment. Occasionally, DO during the normoxic periods spiked above air saturation (DO $>9 \mathrm{mg} / \mathrm{l}, 21.24 \mathrm{kPa}$ ). This occurred in the afternoon (between 1200 and $1600 \mathrm{~h}$ ) after 4-8 $\mathrm{h}$ of oxygen addition to the system. The $\mathrm{pH}$ remained constant at $8.376 \pm 0.001$ in all cyclic hypoxia aquaria throughout the experiment.

Survival during the experiment was excellent. During the first $14 \mathrm{~d}$ of the experiment, survival was $100 \%$ for grass shrimp maintained individually in the normoxic treatment, and $93 \%$ for shrimp exposed to cyclic hypoxic conditions. Mortality was higher during the reproductive portion of the experiment, with overall female survival of $76 \%$ for $\mathrm{HH}$ shrimp, $88 \%$ for HN shrimp, and $60 \%$ for NN shrimp.

There were no significant differences in growth or condition factor within exposures for any shrimp in the experiment, regardless of the number of broods they produced. Additionally, there was no difference in overall growth or condition factor among exposures. Mean overall growth was $-15.7 \pm 11.3 \mathrm{mg}$ for $\mathrm{HH}$ shrimp, $-4.2 \pm 7.5 \mathrm{mg}$ for $\mathrm{HN}$ shrimp, and $-23.1 \pm 43.3 \mathrm{mg}$ for NN shrimp; $K$ ranged from $0.91 \pm 0.03$ in $\mathrm{HH}$ and NN shrimp to $0.94 \pm 0.06$ in HN shrimp. Shrimp generally lost weight during the reproductive experiment, resulting in negative growth. This was particularly evident in the normoxic shrimp, all of which exhibited negative growth. Shrimp that produced no broods also showed little growth during the experiment in all treatments, suggesting that the lack of growth observed is probably not a result of brood production.

\section{Gene expression}

All genes that met the significance criteria of the $t$-test and SAM test were at least 3-fold upregulated or downregu- 


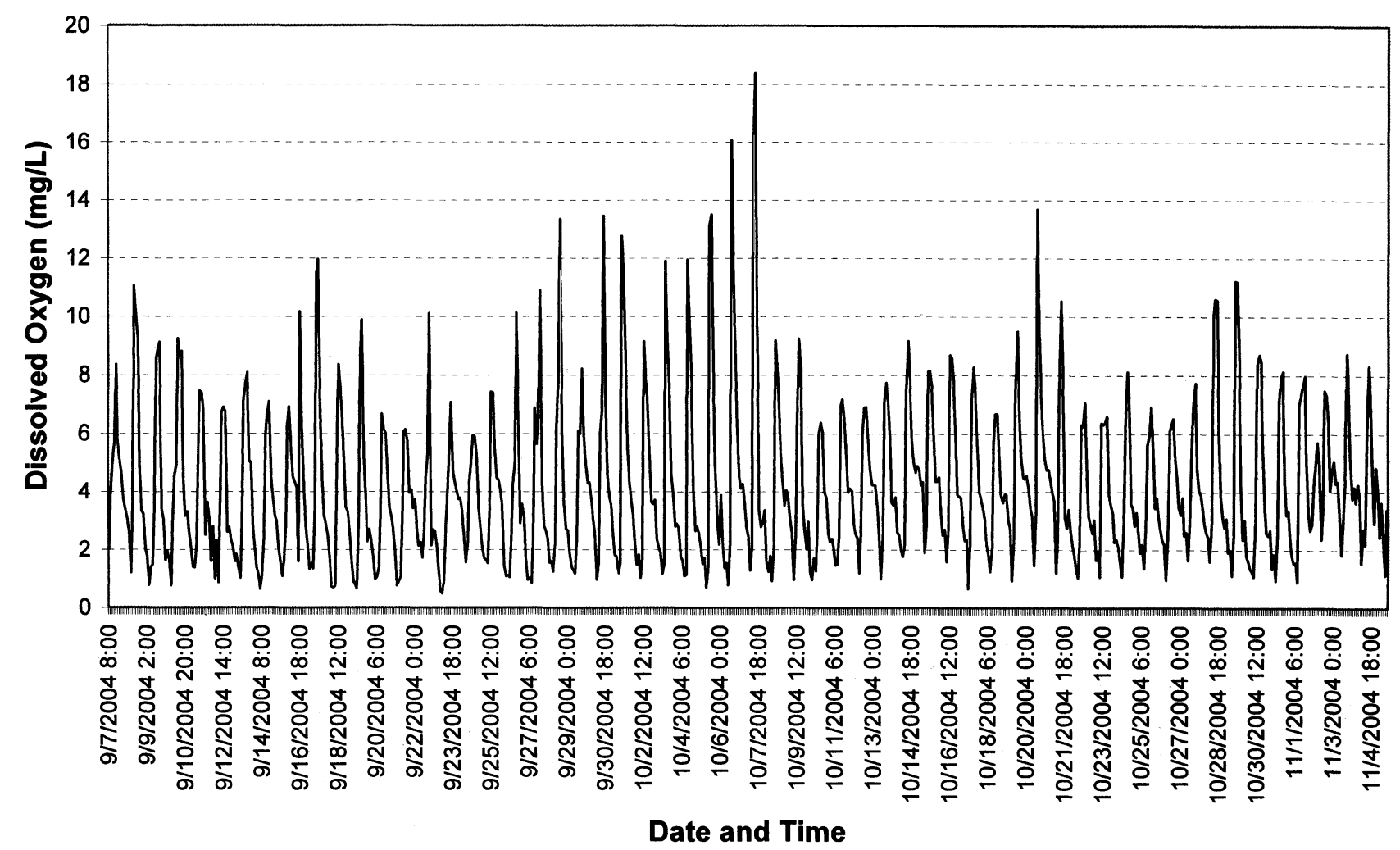

Figure 1. Dissolved oxygen profile of a 77-day cyclic hypoxia experiment. Oxygen was measured every hour throughout the experiment.

lated. A 30-fold downregulation of $H S P 70$ and a 60-fold upregulation of mitochondrial MnSOD ( $m M n S O D)$ was evident after only a 3-d exposure to cyclic hypoxia (Fig. 2A). After $7 \mathrm{~d}$ of exposure, there were significant changes in expression of seven genes (Fig. 2B), including downregulation of genes encoding two ribosomal proteins; two lipid metabolism proteins (very-long-chain specific acyl-CoA dehydrogenase [VLCAD] and sterol reductase); and ATP synthase $\mathrm{d}$. Genes upregulated after $7 \mathrm{~d}$ included genes encoding proteins involved in gluconeogenesis (phosphoenol pyruvate carboxykinase, PEP Cbk) and protein degradation (crustapain). This pattern in gene expression reversed after a 14-d exposure to cyclic hypoxia, with upregulation of genes encoding lipid transport proteins (vitellogenin-1 and apolipoprotein A-1) and cuticle protein (Fig. 2C). Longterm (77-d) continuous exposure of grass shrimp to cyclic hypoxia resulted in no significant changes in gene expression compared to long-term normoxic controls.

\section{Reproduction}

Continuous exposure to cyclic hypoxia appears to decrease the number of broods a female is capable of producing: females exposed to cyclic hypoxia produced only two broods during the 9-week reproduction study, whereas some females mating in normoxia ( $\mathrm{HN}$ and $\mathrm{NN}$ shrimp) were able to produce three broods (Fig 3). Overall, pairs exposed to cyclic hypoxia for 2 weeks but allowed to mate in normoxia (HN) had the highest percentage of females producing first, second, and third broods during the study.

Grass shrimp continuously exposed to cyclic hypoxia had significantly lower relative first-brood fecundity $\left(F_{2,53}=\right.$ 5.92, $P=0.004)$ than the NN shrimp; there were no significant differences in relative fecundity between $\mathrm{HH}$ and $\mathrm{HN}$ or between $\mathrm{NN}$ and $\mathrm{HN}$ shrimp (Table 1). There were no significant differences in relative fecundity among treatments in the second brood produced, with a mean relative fecundity for second broods of $282 \pm 29.7 \mathrm{eggs} / \mathrm{g}$. In addition, there were no significant differences in relative fecundity within any of the exposures for any broods produced, suggesting that fecundity does not decrease over time with continued egg production, regardless of DO exposure. An estimate of total fecundity for the overall study, based on shrimp that produced two broods, shows that normoxic shrimp have a mean relative fecundity 2 times higher than that of shrimp continuously exposed to cyclic hypoxia $\left(F_{2,25}=3.92, P=0.033\right.$; Table 1$)$. Total mean relative fecundity of $\mathrm{HN}$ shrimp was not different from that of $\mathrm{NN}$ or $\mathrm{HH}$ shrimp.

There was no significant difference among exposures in the amount of time it took grass shrimp to produce their first 

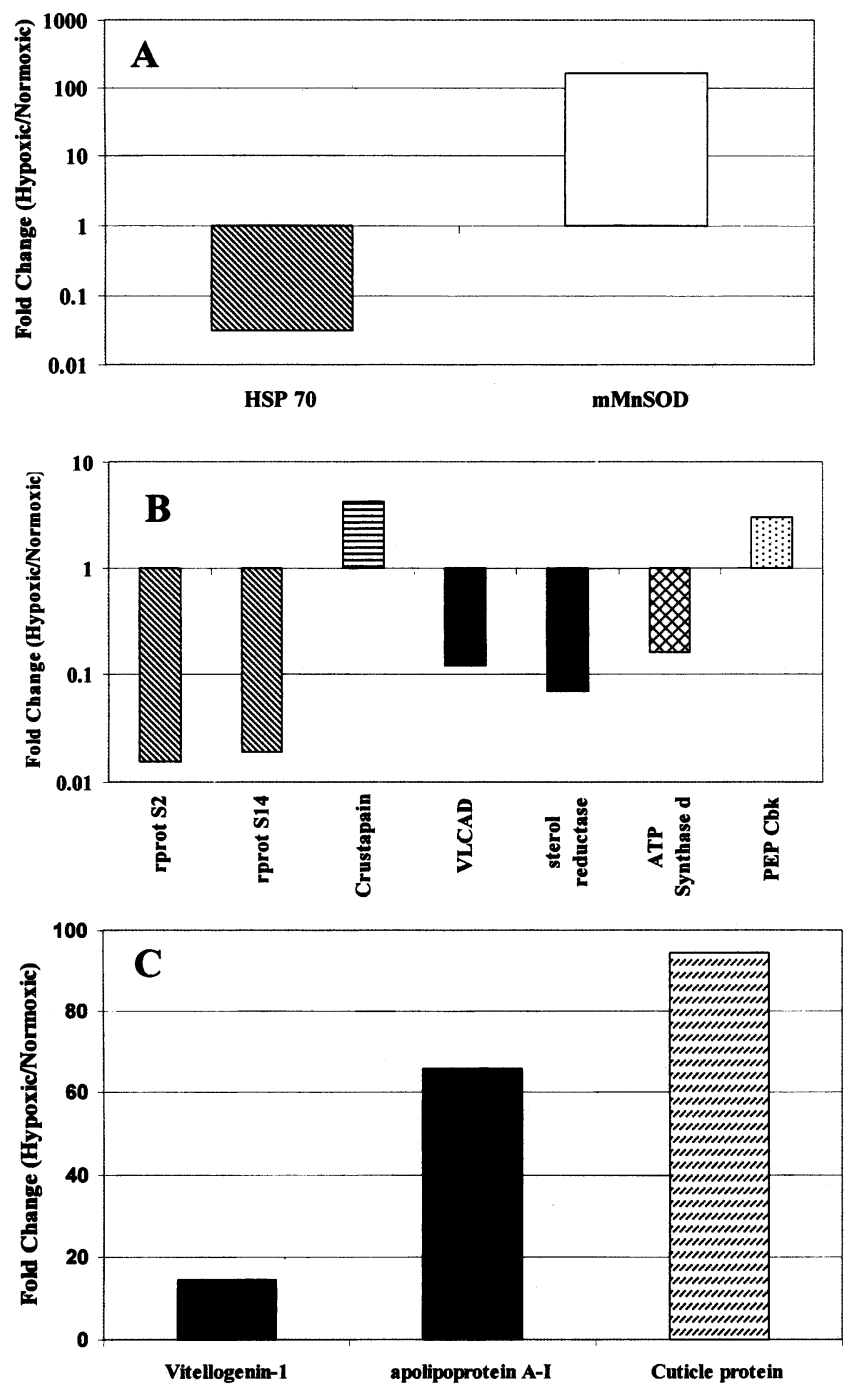

Figure 2. Fold changes (hypoxic/normoxic) in gene regulation of hepatopancreatic tissue, measured by macroarrays in female specimens of Palaemonetes pugio exposed to cyclic $(1.5 \mathrm{mg} / \mathrm{l}-8 \mathrm{mg} / \mathrm{l} \mathrm{DO}, 4.20-18.88$ $\mathrm{kPa}$ ) hypoxia. Data shown were $\log _{2}$-transformed and normalized to the array median prior to calculating fold changes, and all changes are significant $(P \leq 0.05$ [Student's $t$-test], $q<8$ [SAM]). Bar patterns represent gene functional groups. (A) 3-d exposure. (B) 7-d exposure. (C) 14-d exposure. No significant differences were found at $77 \mathrm{~d}$. Gene abbreviations: mMnSOD, mitochondrial Mn-superoxide dismutase; PEP Cbk, phosphoenol pyruvate carboxykinase; rprot S2, mitochondrial ribosomal protein S2; rprot S14, ribosomal protein S14; VLCAD, very-long-chain specific acyl-CoA dehydrogenase.

brood after initial mating with a male, with a mean interbrood interval of $22.2 \pm 1.5 \mathrm{~d}$ (Table 1). However, grass shrimp continuously exposed to cyclic hypoxia took significantly longer to produce a second brood than did HN or NN shrimp $\left(F_{2,30}=9.64, P=0.001\right.$; Table 1$)$. There was no significant difference in interbrood interval between the first and second brood for HH shrimp. However, both $\mathrm{HN}$ and NN shrimp had a significantly shorter interbrood interval for their second brood than for their first brood $(P<0.001$ in both cases; Table 1). An estimate of overall interbrood interval for the 77-d period is not included due to significant interbrood differences within treatments. These results suggest that although grass shrimp continuously exposed to cyclic hypoxia are able to produce the same number of eggs for all broods, it takes them longer to produce a second brood than it takes for shrimp in normoxic conditions.

There was no significant difference in the percentage of larvae that hatched, regardless of exposures or brood number: mean percent hatch for the study was $95.4 \% \pm 0.8 \%$ (Table 1). When considering overall hatching success of shrimp that produced two broods, there was also not a difference among treatments in percentage of larvae that hatched. There was no difference in larval survival across exposures for brood 1 or brood 2, with an overall mean larval survival of $5.9 \pm 0.1 \mathrm{~d}$ (Table 1). Additionally, when considering overall larval survival of shrimp that produced two broods, there were no differences among treatments in larval survival (Table 1). However, in NN shrimp, larval survival of the second brood was significantly reduced compared to the first brood $\left(T_{23}=3.147, P=0.005\right.$; Table 1). A similar decrease in survival with increasing brood number was observed for $\mathrm{HH}$ and $\mathrm{HN}$ shrimp, although the differences were not significant. Taken together, these data suggest that cyclic hypoxia negatively impacts the reproductive potential of adult shrimp but does not affect larval hatch or survival.

Demographic analysis shows a decrease in population growth rate $(\lambda)$ with increasing (14-d to 77-d) exposure to cyclic hypoxic conditions for both brood 1 and brood 2 (Table 2). This suggests that even a limited 14-d exposure to cyclic hypoxic conditions has a negative impact on the growth rate of grass shrimp populations. The $\lambda$ values are significantly higher in NN shrimp than in $\mathrm{HH}$ shrimp for

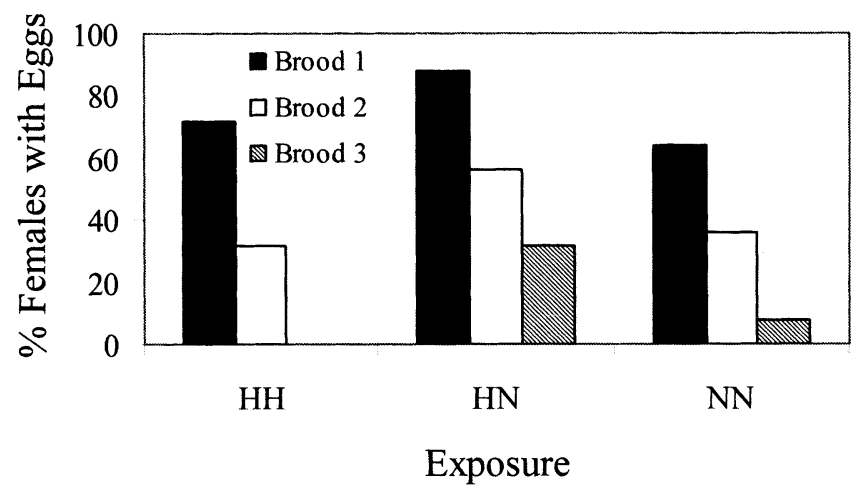

Figure 3. Percentage of female specimens of Palaemonetes pugio that became ovigerous during a 77-d multiple-brood study of cyclic hypoxia $(1.5 \mathrm{mg} / \mathrm{l}-8 \mathrm{mg} / \mathrm{l} \mathrm{DO}, 4.20-18.88 \mathrm{kPa}) ; n=25$ shrimp/treatment. HHmales and females continuously exposed to cyclic hypoxia. $\mathrm{HN}$-males and females exposed to cyclic hypoxia 14 days prior to mating but allowed to mate in normoxia $(8 \mathrm{mg} / \mathrm{l} \mathrm{DO}) . \mathrm{NN}$-males and females continuously exposed to normoxia. 
Table 1

Reproductive parameters (mean $\pm S E$ ) of female specimens of Palaemonetes pugio in a multiple-brood study of cyclic hypoxia

\begin{tabular}{|c|c|c|c|c|c|c|}
\hline \multirow[t]{3}{*}{$\mathrm{HH}$} & 1 & 18 & ${ }^{\mathrm{a}} 159.8 \pm 19.0$ & $22.1 \pm 2.4$ & $94.9 \pm 1.4$ & $6.2 \pm 0.2$ \\
\hline & 2 & 5 & $173.1 \pm 50.6$ & ${ }^{\mathrm{a}} 18.5 \pm 1.9$ & $89.9 \pm 6.1$ & $5.3 \pm 0.4$ \\
\hline & $1+2$ & 5 & ${ }^{a} 360.0 \pm 83.3$ & - & $92.8 \pm 3.2$ & $5.9 \pm 0.3$ \\
\hline \multirow[t]{3}{*}{$\mathrm{HN}$} & 1 & 20 & a,b $267.6 \pm 28.0$ & $23.9 \pm 3.1^{x}$ & $95.1 \pm 2.4$ & $5.8 \pm 0.3$ \\
\hline & 3 & 2 & $354.5 \pm 33.5$ & ${ }^{\mathrm{c}} 11.5 \pm 0.4^{\mathrm{y}}$ & $95.6 \pm 0.6$ & $4.5 \pm 0.0$ \\
\hline & $1+2$ & 14 & a,b $560.9 \pm 56.2$ & - & $94.8 \pm 1.7$ & $5.6 \pm 0.2$ \\
\hline \multirow[t]{3}{*}{ NN } & 1 & 16 & $\mathrm{~b}_{373.7} \pm 40.9$ & $20.3 \pm 1.5^{\mathrm{x}}$ & $96.4 \pm 0.9$ & $6.6 \pm 0.3^{x}$ \\
\hline & 2 & 9 & $345.2 \pm 74.2$ & ${ }^{\mathrm{b}} 9.8 \pm 1.9^{\mathrm{y}}$ & $98.0 \pm 0.7$ & $5.3 \pm 0.3^{y}$ \\
\hline & $1+2$ & 9 & ${ }^{b} 725 \pm 97.0$ & - & $96.4 \pm 0.8$ & $6.0 \pm 0.3$ \\
\hline
\end{tabular}

$n$ based on number of shrimp that carried a brood through hatch. Broods $1+2$ represent combined values for shrimp that produced 2 broods. HH-females continuously exposed to cyclic hypoxia (1.5-8 mg/l DO, 4.20-18.88 kPa) over $24 \mathrm{~h}$ for 77 days; $\mathrm{HN}$-females exposed to cyclic hypoxia for 2 weeks prior to mating and allowed to mate in normoxia $(8 \mathrm{mg} / \mathrm{l} \mathrm{DO})$; $\mathrm{NN}$-females continuously exposed to normoxia $(8 \mathrm{mg} / \mathrm{l} \mathrm{DO})$ for $77 \mathrm{days}$. Superscripts a-c represent significant differences among exposures within a brood; superscripts $\mathrm{x}-\mathrm{y}$ represent significant differences among broods within an exposure.

brood 1 , as indicated by the fact that the $95 \%$ confidence intervals $(\mathrm{CI})$ of the mean values do not overlap. Although small samples sizes confound the comparison of $95 \%$ CIs in brood 2, clearly the $\lambda \mathrm{CI}$ values for the $\mathrm{HH}$ and $\mathrm{HN}$ shrimp do not overlap. In addition, population growth rate increased significantly between brood 1 and brood 2 for both $\mathrm{HH}$ and $\mathrm{HN}$ exposures (Table 2). The differences in relative fecundity and interbrood interval observed among treatments and broods (Table 1) indicate that relative fecundity contributes mostly to differences in population growth rate for brood 1 , whereas interbrood interval has the greatest effect on $\lambda$ for brood 2. Larval survival, calculated as hatching success rate for these experiments, appears to have the smallest influence on population growth rate.

\section{Discussion}

In response to cyclic DO, grass shrimp of the species Palaemonetes pugio show discrete changes in gene expres-

Table 2

Estimates of population growth rate $(\lambda)$ for specimens of Palaemonetes pugio in a multiple-brood study of cyclic hypoxia

\begin{tabular}{ccc}
\hline \hline Treatment & Brood 1 & Brood 2 \\
\hline & & \\
$\mathrm{HH}$ & $1.2169(1.1686-1.2609)$ & $1.2654(1.2610-1.2697)$ \\
$\mathrm{HN}$ & $1.2248(1.1527-1.2924)$ & $1.5201(1.5066-1.5336)$ \\
$\mathrm{NN}$ & $1.2916(1.2544-1.3287)$ & $1.6880(1.2557-2.1203)$ \\
\hline
\end{tabular}

HH-females continuously exposed to cyclic hypoxia (1.5-8 mg/l DO, 4.20-18.88 kPa) over $24 \mathrm{~h}$ for $77 \mathrm{~d}$. HN-females exposed to cyclic hypoxia for 2 weeks prior to mating and allowed to mate in normoxia (8 $\mathrm{mg} / \mathrm{l} \mathrm{DO}) . \mathrm{NN}$-females continuously exposed to normoxia (8 mg/l DO) for 77 days. Numbers represent $\lambda$ and $95 \%$ confidence limits. sion that are dependent on the duration of exposure. The observed changes differ from those induced by exposure to chronic hypoxia (Brouwer et al., 2007). These distinct responses suggest that gene expression profiles might be used to distinguish between shrimp that experience stress associated with exposure to chronic and cyclic hypoxia. After $3 \mathrm{~d}$ of cyclic DO, HSP70 is downregulated, whereas mitochondrial MnSOD is dramatically ( $>100$-fold) upregulated. Although cellular stress usually produces an upregulation of HSP70 to assist with re-folding of partially denatured proteins (Kultz, 2003), a similar downregulation of HSP70 was observed in grass shrimp exposed to $7 \mathrm{~d}$ of moderate hypoxia (2.5 mg/1; Brouwer et al., 2007; Table 3). We speculate that the commonly observed decrease in protein synthesis in response to hypoxia (Hochachka et al., 1996; Gracey et al., 2001) may account for the decrease in expression of HSP70, which is also involved in folding of newly synthesized proteins (Beckman et al., 1990). The increase in transcription of superoxide dismutase (SOD) is a common response to oxidative stress, previously observed in blue crabs exposed to copper (Brouwer and Hoexum-Brouwer, 1998) and to cyclic DO (Brown-Peterson et al., 2005). The upregulation of mitochondrial MnSOD after $3 \mathrm{~d}$ of cyclic DO is in marked contrast to the downregulation of cytosolic MnSOD in grass shrimp exposed to moderate hypoxia for $14 \mathrm{~d}$ (Brouwer et al., 2007; Table 3). In general, hypoxia leads to downregulation of antioxidant defense systems, whereas oxidative stress results in upregulation of these systems ( $\mathrm{Yu}$, 1994; Choi et al., 2000). The upregulation of oxygen transport proteins and ATP synthases that occurs in grass shrimp after $3 \mathrm{~d}$ of severe chronic hypoxic $(1.5 \mathrm{mg} / \mathrm{l})$ exposure (Brouwer et al., 2007) is never observed at any time point during the cylic DO exposures (Table 3 ). 
Table 3

Comparison of gene expression profiles in specimens of Palaemonetes pugio exposed to chronic (moderate, $2.5 \mathrm{mg} / \mathrm{DO}, 7.01 \mathrm{kPa} ; \mathrm{severe}, 1.5 \mathrm{mg} / \mathrm{l}$ $\mathrm{DO}, 4.20 \mathrm{kPa})^{a}$ or cyclic $(1.5-8 \mathrm{mg} / \mathrm{l} \mathrm{DO}, 4.20-22.42 \mathrm{kPa})$ hypoxia

\begin{tabular}{|c|c|c|c|c|c|c|}
\hline \multirow[b]{2}{*}{ Time point } & \multicolumn{2}{|c|}{ Chronic moderate } & \multicolumn{2}{|c|}{ Chronic severe } & \multicolumn{2}{|c|}{ Cyclic } \\
\hline & Upreg & Downreg & Upreg & Downreg & Upreg & Downreg \\
\hline 3 days & - & - & $\begin{array}{l}\text { ATP syn-d } \\
\text { ATP syn-f } \\
\text { HcyI, II, III } \\
\text { Ferritin }\end{array}$ & - & $\mathrm{mMnSOD}$ & HSP70 \\
\hline 7 days & - & HSP70 & $\begin{array}{l}\text { 16S rRNA } \\
\text { Ccox1 } \\
\text { Heme BP } \\
\text { Ferritin }\end{array}$ & - & $\begin{array}{l}\text { Crustapain } \\
\text { PEP Cbk }\end{array}$ & $\begin{array}{l}\text { rprot S2, S14 } \\
\text { VLCAD } \\
\text { Sterol reductase } \\
\text { ATP syn-d }\end{array}$ \\
\hline 14 days & - & cMnSOD & - & $\begin{array}{l}\text { 16S rRNA } \\
\text { Ccox } 1,3 \\
\text { Cytb } \\
\text { Ferritin }\end{array}$ & $\begin{array}{l}\text { Vitellogenin } \\
\text { Apoliprotein } \\
\text { Cuticle protein }\end{array}$ & - \\
\hline
\end{tabular}

${ }^{\text {a }}$ From Brouwer et al. (2007).

Abbreviations: $16 \mathrm{~S}$ rRNA, ribosomal RNA 16S; ATP syn-d, ATP synthase d chain; ATP syn-f, ATP synthase f chain; Ccox1, cytochrome $c$ oxidase

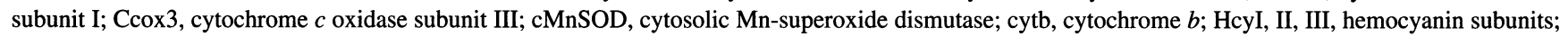

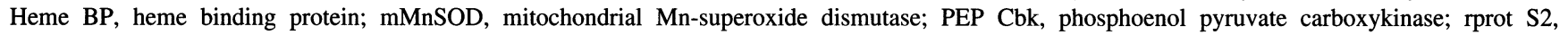
mitochondrial ribosomal protein S2; rprot S14, ribosomal protein S14; VLCAD, very-long-chain specific acyl-CoA dehydrogenase.

After $7 \mathrm{~d}$ there is a marked change in expression of nuclear genes that encode proteins involved in mitochondrial function. Ribosomal protein S2 (a constituent of mitochondrial ribosomes), ATP synthase $d$ chain, and the mitochondrial enzyme VLCAD are downregulated. VLCAD catalyzes the first step in the $\beta$-oxidation of longchain fatty acids such as palmitate, resulting in the production of acetyl-CoA. Inhibition of palmitate degradation, followed by upregulation of the palmitate transport protein apolipoprotein A1 after a 14-d exposure (see below), strongly suggests export of fatty acids from the hepatopancreas to other tissues to serve as a source of energy. The gene encoding PEP Cbk, which plays a crucial role in gluconeogenesis and converts oxaloacetate into PEP (Ogata et al., 1982), is upregulated. The latter enzyme can occur in either mitochondria or cytosol. Molecular phylogenetic analysis shows that the sequence of PEP Cbk on our macroarrays clusters firmly with the mitochondrial form of the enzyme (Brouwer, unpubl. results). Concurrently, an upregulation of the gene for the proteolytic enzyme crustapain, which may help deliver amino acids for the gluconeogenic pathway, suggests increased gluconeogenesis, to maintain blood glucose levels, occurring in the hepatopancreas. The diversion of oxaloacetate, whose concentration tends to be limiting for the tricarboxylic acid (TCA) cycle, and decreased production of acetyl-CoA, due to decreased fatty acid oxidation, may result in inhibition of the TCA cycle.

The response to $7 \mathrm{~d}$ of cyclic DO differs markedly from the response to $7 \mathrm{~d}$ of severe chronic hypoxia, which results in upregulation of genes in the mitochondrial genome to- gether with genes involved in heme $(\mathrm{Fe})$ metabolism (Table $3)$. It is rather remarkable, though, that a shutdown of mitochondrial function is observed after $14 \mathrm{~d}$ of severe chronic hypoxia (Table 3). However, the mechanism through which this is accomplished is entirely different from the mechanism hypothesized above, and involves downregulation of proteins that are constituents of the electron transport chain.

After $14 \mathrm{~d}$ of cyclic DO, the inhibition of the TCA cycle has been lifted and the response has shifted toward upregulation of genes encoding the lipid-transport proteins vitellogenin and apoliprotein A1, together with upregulation of an arthrodial membrane protein that is similar to blue crab AMP9.3 (Faircloth and Shafer, 2007). The grass shrimp apolipoprotein A1 shows greatest homology with that of fish (carp and eel), which has been shown to transport free fatty acids, including the long-chain fatty acid palmitate (Metcalf et al., 1999; De Smet et al., 2004). The upregulation of the yolk protein vitellogenin might have been expected to increase larval survival; however, survival of hypoxic and normoxic larvae was found to be the same. Finally, $77 \mathrm{~d}$ in cyclic DO failed to produce any differences in gene expression between hypoxic and control shrimp. Thus the response to cyclic DO at the level of gene expression apparently occurs during the first 2 weeks of exposure, with distinct differences between days 3,7 , and 14, after which gene expression profiles appear to return to preexposure levels.

Cyclic hypoxia dramatically affects short-term gene expression, as discussed above. Our data also indicate that 
cyclic DO impairs long-term reproductive fitness in grass shrimp, and that these impacts may have population-level implications, as indicated by estimates of population growth rates. These results have important environmental ramifications, since shallow estuarine systems, which serve as nursery grounds for many juvenile fish and shellfish species, commonly experience cyclic hypoxia, particularly during the summer reproductive season. However, most previous work on the effects of hypoxia on estuarine organisms has focused on chronic hypoxia, which is more commonly found in deep open-bay systems. Few studies have examined cyclic hypoxia or compared effects of chronic and cyclic hypoxia. Tyler and Targett (2007) reported that juvenile weakfish, Cynoscion regalis, actively exploit habitats that commonly experience cyclic hypoxia, leaving only briefly when oxygen falls below $2 \mathrm{mg} / \mathrm{l} \mathrm{O}_{2}$. Coiro et al. (2000) found that although the growth of the grass shrimp $P$. vulgaris was less impaired by exposure to cyclic hypoxia than to chronic hypoxia, exposure to any hypoxia resulted in less growth than under normal oxygen conditions. Similar results have been documented in fishes-both freshwater (Stewart et al., 1967; Whitworth, 1968) and marine (Stierhoff et al., 2006) species. However, McNatt and Rice (2004) found growth of juvenile spot, Leiostomus xanthurus, was not affected by cyclic hypoxia, which is similar to results reported here for grass shrimp.

Continuous exposure to cyclic hypoxia $(\mathrm{HH})$ resulted in shrimp that produced fewer broods than did $\mathrm{NN}$ or $\mathrm{HN}$ shrimp, but the percentage of females producing one or two broods was similar across treatments. In contrast, the percentage of ovigerous females was lower in grass shrimp exposed to the insecticide endosulfan (Wirth et al., 2002), grass shrimp collected from a mercury- and PCP-contaminated site (Wall et al., 2001), and grass shrimp collected at sites with high runoff of agriculture pesticide (Leight $e t$ al., 2005) than it was in controls, although shrimp were not given an opportunity to produce multiple broods in these studies. These data indicate that the reproductive potential of grass shrimp exposed to both anthropogenic and natural stressors is reduced.

The decrease in fecundity of grass shrimp exposed to cyclic hypoxia was expected, although this contradicts our previously surprising findings of increased fecundity in grass shrimp exposed to chronic hypoxia (Brouwer et al., 2007). The decrease in fecundity was observed for the first brood produced; there is apparently no difference in fecundity of grass shrimp producing a second brood when exposed to either chronic (Brouwer et al., 2007) or cyclic (this study) hypoxia. However, total fecundity over the course of this study for shrimp producing two broods was significantly lower for $\mathrm{HH}$ shrimp than NN shrimp, suggesting that cyclic hypoxia may have a marked long-term effect on grass shrimp reproductive potential. Similar results were found for grass shrimp exposed to agricultural pesticide runoff (Leight et al., 2005). In general, fecundity may not be the best indicator of exposure stress in grass shrimp, as females exposed to pyrene (Oberdorster et al., 2000), mercury and PCBs (Wall et al., 2001), the insecticide endosulfan (Wirth et al., 2002), and the pesticides chlorpyrifos and fipronil (Volz et al., 2003) did not show a reduction in fecundity compared to controls. In contrast, interbrood interval appears to be a more sensitive indicator of reproductive dysfunction, as grass shrimp exposed to both chronic (Brouwer et al., 2007) and cyclic hypoxia had longer interbrood intervals than grass shrimp held in normoxic conditions.

In the natural environment, hypoxia is often associated with hypercapnia (high $\mathrm{CO}_{2}$ and hence low $\mathrm{pH}$ ), which is a result of high rates of benthic respiration. The combination of hypoxia and hypercapnia can significantly affect physiological processes (Burnett, 1997). However, oxygen uptake and whole-body lactate concentrations in $P$. pugio under normoxic and hypoxic conditions appear to be minimally impacted by increased $\mathrm{PCO}_{2}$ (Cochran and Burnett, 1996), indicating that hypercapnia does not affect the respiratory response of grass shrimp to hypoxia. Furthermore, hypercapnia is not a potentially confounding factor in the experiments described here, since hypoxic conditions were produced by bubbling nitrogen into the aquaria and the $\mathrm{pH}$ in the cyclic hypoxia aquaria remained steady at 8.3 throughout the 77-d experiment.

The population-level consequences of cyclic hypoxia are demonstrated by a lower rate of population growth $(\lambda)$ in grass shrimp exposed to cyclic hypoxia on both a continuous and a short-term basis when compared to normoxic shrimp. Our data provide estimates of population growth rate on a per-brood basis under laboratory conditions. A new, individual-based matrix projection model of a marsh community (Sable, 2007), developed on the basis of our laboratory data, predicted that low DO would decrease total annual production of grass shrimp as a result of fewer individuals, reduced growth rate, and death from starvation. This model provides an estimate of growth over the lifetime of a grass shrimp population that supports the estimates presented here that are based on individual broods. It is important to note that the population growth rate estimates provided here do not account for adult or larval survival beyond hatching, factors that have been shown to significantly affect $\lambda$ in wild animal populations (Gleason et al., 2000; McGee and Spencer, 2001; Reid et al., 2004; Gerber et al., 2004). Thus, the $\lambda$ estimates presented here must be regarded as preliminary values suggesting no more than a trend. Furthermore, the decrease in $\lambda$ observed in grass shrimp exposed to cyclic hypoxia for only 2 weeks and allowed to mate in normoxia (HN group) compared to values for the normoxic group indicates that continuous exposure to cyclic hypoxia is not necessary for adverse population-level effects. Many sites along the Gulf of Mex- 
ico and Atlantic coasts exhibit short-term, rather than chronic, cyclic hypoxia (USEPA, 2000). Thus, population metrics of grass shrimp from those sites that exhibit shortterm cyclic hypoxia may be negatively impacted, with resulting consequences to the health and function of the entire ecosystem.

\section{Acknowledgments}

We thank C. King and K. Ryan for assistance with shrimp husbandry and sampling. This research was supported by grants to M.B. from the US Environmental Protection Agency's Science to Achieve Results (STAR) Estuarine and Great Lakes (EaGLe) program through funding to the Consortium for Estuarine Ecoindicator Research for the Gulf of Mexico (CEER-GOM; US EPA Agreement R82945801) and from the National Oceanic and Atmospheric Administration (NAO3NOS4260216). Although the research described in this article was funded wholly or in part by the US EPA, it has not been subjected to the Agency's required peer and policy review and, therefore, does not necessarily reflect the views of the Agency and no official endorsement should be inferred.

\section{Literature Cited}

Aoyama, T., I. Uenot, T. Kamijo, and T. Hashimoto. 1994. Rat verylong-chain acyl-CoA dehydrogenase, a novel mitochondrial acyl-CoA dehydrogenase gene product, is a rate-limiting enzyme in long-chain fatty acid $\beta$-oxidation system. J. Biol. Chem. 269: 19088-19094.

Beckman, R. P., L. A. Missen, and W. J. Welch. 1990. Interaction of Hsp 70 with newly-synthesized proteins: implications for protein folding and assembly. Science 248: 850-854.

Bell, G. W., and D. B. Eggleston. 2005. Species-specific avoidance responses by blue crabs and fish to chronic and episodic hypoxia. Mar. Biol. 146:761-770.

Bell, G. W., D. B. Eggleston, and T. G. Wolcott. 2003. Behavioral responses of free-ranging blue crabs to episodic hypoxia. I. Movement. Mar. Ecol. Prog. Ser. 259: 215-225.

Brouwer, M., and T. Hoexum-Brouwer. 1998. Biochemical defense mechanisms against copper-induced oxidative stress in the blue crab (Calinectes sapidus). Arch. Biochem. Biophys. 351: 257-264.

Brouwer, M., N. J. Brown-Peterson, P. Larkin, S. Manning, N. Denslow, and K. Rose. 2005. Molecular and organismal indicators of chronic and intermittent hypoxia in marine crustacea. Pp. 261-276 in Estuarine Indicators, S.A. Bortone, ed. CRC Press, Boca Raton, FL.

Brouwer, M., N. J. Brown-Peterson, P. Larkin, V. Patel, N. Denslow, S. Manning, and T. Hoexum Brouwer. 2007. Molecular and whole animal responses of grass shrimp, Palaemonetes pugio, exposed to chronic hypoxia. J. Exp. Mar. Biol. Ecol. 341: 16-31.

Brown-Peterson, N. J., P. Larkin, N. Denslow, C. King, C. Manning, and M. Brouwer. 2005. Molecular indicators of hypoxia in the blue crab Callinectes sapidus. Mar. Ecol. Prog. Ser. 286: 203-215.

Burnett, L. E. 1997. The challenges of living in hypoxia and hypercapnic aquatic environments. Am. Zool. 37: 633-640.

Buzzelli, C. P., R. A. Luettich, S. P. Powers, C. H. Peterson, J. E. McNinch, J. L. Pinckney, and H. W. Paerl. 2002. Estimating the spatial extent of bottom-water hypoxia and habitat degradation in a shallow estuary. Mar. Ecol. Prog. Ser. 230: 103-112.

Choi, J., H. Roche, and T. Caquet. 2000. Effects of physical (hypoxia, hyperoxia) and chemical (potassium dichromate, fenithrothion) stress on antioxidant enzyme activities in Chironomus riparius $\mathrm{Mg}$ (Dipteria, Chironomidae) larvae: potential biomarkers. Environ. Toxicol. Chem. 19: 495-500.

Cochran, R. E., and L. E. Burnett. 1996. Respiratory responses of the salt marsh animals, Fundulus heteroclitus, Leiostomus xanthurus, and Palaemonetes pugio to environmental hypoxia and hypercapnia and to the organophosphate pesticide, azinosmethyl. J. Exp. Mar. Biol. Ecol. 195: $125-144$.

Coiro, L. L., S. L. Poucher, and D. C. Miller. 2000. Hypoxic effects on growth of Palaemonetes vulgaris larvae and other species: using constant exposure data to estimate cyclic exposure response. J. Exp. Mar. Biol. Ecol. 247: 243-255.

Craig, J. K., L. B. Crowder, and T. A. Henwood. 2005. Spatial distribution of brown shrimp (Farfantepenaeus aztecus) on the northwestern Gulf of Mexico shelf: effects of abundance and hypoxia. Can. J. Fish. Aquat. Sci. 62: 1295-1308.

David, E., A. Tanguy, K. Pichavant, and D. Moraga. 2005. Responses of the Pacific oyster Crassostrea gigas to hypoxia exposure under experimental conditions. FEBS J. 272: 5635-5652.

DeFur, P. L., C. P. Mangum, and J. E. Reese. 1990. Respiratory responses of the blue crab Callinectes sapidus to long-term hypoxia. Biol. Bull. 178: 46-54.

De Smet, H., R. Blust, and L. Moens. 2004. Absence of albumin in the plasma of the common carp Cyprinus carpio: binding of fatty acids to high density lipoprotein. Fish Physiol. Biochem. 19: 71-81.

Diaz, R. J., and R. Rosenberg. 1995. Marine benthic hypoxia: a review of its ecological effects and the behavioural responses of benthic macrofauna. Oceanogr. Mar. Biol. Annu. Rev. 33: 245-303.

Eby, L. A., L. B. Crowder, C. M. McClellan, C. H. Peterson, and M. J. Powers. 2005. Habitat degradation from intermittent hypoxia: impacts on demersal fishes. Mar. Ecol. Prog. Ser. 291: 249-261.

Faircloth, L. M., and T. H. Shafer. 2007. Differential expression of eight transcripts and their roles in the cuticle of the blue crab, Callinectes sapidus. Comp. Biochem. Physiol. B Biochem. Mol. Biol. 146: 370-383.

Forbes, V. E., and A. Cold. 2005. Effects of the pyrethroid esfenvalerate on life-cycle traits and population dynamics of Chironomus ripariusimportance of exposure scenario. Environ. Toxicol. Chem. 24: 78-86.

Gerber, L. R., K. E. Buenau, and G. Vanblaricom. 2004. Density dependence and risk of extinction in a small population of sea otters. Biodivers. Conserv. 13: 2741-2757.

Gleason, T. R., W. R. Munns, and D. E. Nacci. 2000. Projecting population-level responses of purple sea urchins to lead contamination for an estuarine ecological risk assessment. J. Aquat. Ecosyst, Stress Recovery 7: 177-185.

Gracey, A. Y., J. V. Troll, and G. N. Somero. 2001. Hypoxia-induced gene expression profiling in the euryoxic fish Gillichthys mirabilis. Proc. Natl. Acad. Sci. USA 98: 1993-1998.

Hochachka, P. W., L. T. Buck, C. J. Doll, and S. C. Land. 1996. Unifying theory of hypoxia tolerance: molecular/metabolic defense and rescue mechanisms for surviving oxygen lack. Proc. Natl. Acad. Sci. USA 93: 9493-9498.

Key, P. B., E. F. Wirth, and M. H. Fulton. 2006. A review of grass shrimp, Palaemonetes spp., as a bioindicator of anthropogenic impacts. Environ. Bioindic. 1: 115-128.

Kultz, D. 2003. Evolution of the cellular stress proteome: from monophyletic origin to ubiquitous function. J. Exp. Biol. 206: 3119-3124.

Larkin, P., L. C. Folmar, M. J. Hemmer, A. J. Poston, and N. D. Denslow. 2003. Expression profiling of estrogenic compounds using a sheepshead minnow cDNA macroarray. Environ. Health Persp. Toxicogenomics 111: 839-846.

Leight, A. K., G. I. Scott, M. H. Fulton, and J. W. Daugomah. 2005. Long term monitoring of grass shrimp Palaemonetes spp. population 
metrics at sites with agricultural runoff influences. Integr. Comp. Biol. 45: $143-150$.

Mangum, C. P. 1997. Adaptation of the oxygen transport system to hypoxia in the blue crab, Callinectes sapidus. Am. Zool. 37: 604-611.

Manning, C. S., A. L. Schesny, W. E. Hawkins, D. H. Barnes, D. S. Barnes, and W. W. Walker. 1999. Exposure methodologies and systems for long term chemical carcinogenicity studies with small fish species. Toxicol. Methods 9: 201-217.

McGee, B. L., and M. Spencer. 2001. A field-based population model for the sediment toxicity test organism Leptocheirus plumulosus: model application. Mar. Environ. Res. 51: 347-363.

McMahon, B. R. 2001. Respiratory and circulatory compensation to hypoxia in crustaceans. Respir. Physiol. 128: 349-364.

McNatt, R. A., and J. A. Rice. 2004. Hypoxia-induced growth rate reduction in two juvenile estuary-dependent fishes. J. Exp. Mar. Biol. Ecol. 311: 147-156.

Meehean, O. L. 1936. Notes on the freshwater shrimp Palaemonetes paludosa (Gibbes). Trans. Am. Microsc. Soc. 55: 433-441.

Metcalf, V. J., S. O. Brennan, G. Chambers, and P. M. George. 1999. High density lipoprotein (HDL), and not albumin, is the major palmitate binding protein in New Zealand long-finned (Anguila dieffenbachia) and short-finned (Anguila australis schmidtii) eel plasma. Biochim. Biophys. Acta 1429: 467-475.

Nestlerode, J. A., and R. J. Diaz. 1998. Effects of periodic environmental hypoxia on predation of a tethered polychaete, Glycera americana: implications for trophic dynamics. Mar. Ecol. Prog. Ser. 172: 185-195.

Oberdorster, E., M. Brouwer, T. Hoexum-Brouwer, S. Manning, and J. McLachlan. 2000. Long-term pyrene exposure of grass shrimp, Palaemonetes pugio, affects molting and reproduction of exposed males and offspring of exposed females. Environ. Health Persp. 108: 641-646.

Ogata, K., M. Watford, L. J. Brady, and R. W. Hanson. 1982. Mitochondrial phosphoenolpyruvate carboxykinase (GTP) and the regulation of gluconeogenesis and ketogenesis in avian liver. J. Biol. Chem. 257: 5385-5391.

Paerl, H. W., J. L. Pinckney, J. M. Fear, and B. L. Peierls. 1998. Ecosystem responses to internal and watershed organic matter loading: consequences of hypoxia in the eutrophying Neuse river estuary, North Carolina, USA. Mar. Ecol. Prog. Ser. 166: 17-25.

Paul, R. J., B. Zeis, T. Lamkemeyer, M. Seidl, and R. Pirow. 2004. Control of oxygen transport in the microcrustacean Daphnia: regulation of haemoglobin expression as central mechanism of adaptation to different oxygen and temperature conditions. Acta Physiol. Scand. 182: 259-275.

Rabalais, N. N., R. E. Turner, and W. J. Wiseman. 2002. Gulf of Mexico hypoxia, a.k.a. "The dead zone." Annu. Rev. Ecol. Syst. 33: 235-263.

Reid, J. M., E. M. Bignal, S. Bignal, D. I. McCracken, and P. Monaghan. 2004. Identifying the demographic determinants of population growth rate: a case study of red-billed choughs Pyrrhocorax pyrrhocorax. J. Anim. Ecol. 73: 777-788.

Ringwood, A. H., and C. J. Keppler. 2002. Water quality variation and clam growth: Is pH really a non-issue in estuaries? Estuaries 25: 901-907.

Sable, S. E. 2007. A comparison of individual-based and matrix projection models applied to fish population and community dynamics. Ph.D. dissertation, Louisiana State University, Baton Rouge.

Sanford, L. P., K. G. Sellner, and D. E. Breitburg. 1990. Covariability of dissolved oxygen with physical processes in the summertime Chesapeake Bay. J. Mar. Res. 48: 567-590.
Sokal, R. R., and F. J. Rohlf. 1995. Biometry, 3rd ed. W.H. Freeman, New York.

Stewart, N. E., D. L. Shumway, and P. Doudoroff. 1967. Influence of oxygen concentration on the growth of juvenile largemouth bass. $J$. Fish. Res. Bd. Can. 24: 475-494.

Stierhoff, K. L., T. E. Targett, and K. Miller. 2006. Ecophysiological responses of juvenile summer and winter flounder to hypoxia: experimental and modeling analyses of effects on estuarine nursery quality. Mar. Ecol. Prog. Ser. 325: 255-266.

Terwilliger, N. B. 1998. Functional adaptations of oxygen-transport proteins. J. Exp. Biol. 201: 1085-1098.

Ton, C., D. Stamatiou, V. J. Dzau, and C.-C. Liew. 2002. Construction of a zebrafish cDNA microarray: gene expression profiling of the zebrafish during development Biochem. Biophys. Res. Comm. 296: 1134-1142.

Ton, C., D. Stamatiou, and C.-C. Liew. 2003. Gene expression profile of zebrafish exposed to hypoxia during development. Physiol. Genomics 13: 97-106.

Turner, R. E., and N. N. Rabalais. 1994. Coastal eutrophication near the Mississippi delta. Nature 368: 619-621.

Tusher V. G., R. Tibshirani, and G. Chu. 2001. Significance analysis of microarrays applied to the ionizing radiation response. Proc. Natl. Acad. Sci. USA 98: 5116-5121.

Tyler, R. M., and T. E. Targett. 2007. Juvenile weakfish, Cynoscion regalis, distribution in relation to diel-cycling dissolved oxygen in an estuarine tributary. Mar. Ecol. Prog. Ser. 333: 257-269.

USEPA. 2000. Ambient Aquatic Life Water Quality Criteria for Dissolved Oxygen (Saltwater): Cape Cod to Cape Hatteras. EPA-822-R00-012. Washington, DC.

van der Meer, D. L. M., G. E. E. J.M. van den Thillart, F. Witte, M. A. G. de Bakker, J. Besser, M. K. Richardson, H. P. Spaink, J. T. D. Leito, and C. P. Batowski. 2005. Gene expression profiling of the long-term adaptive response to hypoxia in the gills of adult zebrafish. Am. J. Physiol. Regul. Integr. Comp. Physiol. 289: 15121519.

Volz, D. C., E. Wirth, M. Fulton, G. Scott, E. Strozier, D. Block, J. Ferry, S. Walse, and G. Chandler. 2003. Effects of fipronil and chlorpyrifos on endocrine-related endpoints in female grass shrimp (Palaemonetes pugio). Bull. Environ. Contam. Toxicol. 71: 407-503.

Wall, V. D., J. J. Alberts, D. J. Morre, S. Y. Newell, M. Pattanayek, and S. C. Pennings. 2001. The effect of mercury and PCBs on organisms from lower trophic levels of a Georgia salt marsh. Arch. Environ. Contam. Toxicol. 40: 10-17.

Wannamaker, C. M., and J. A. Rice. 2000. Effects of hypoxia on movements and behavior of selected estuarine organisms from the southeastern United States. J. Exp. Mar. Biol. Ecol. 249: 145-163.

Welsh, B. L. 1975. The role of grass shrimp, Palaemonetes pugio, in a tidal marsh ecosystem. Ecology 56: 513-530.

Whitworth, W. R. 1968. Effects of diurnal fluctuations of dissolved oxygen on the growth of brook trout. J. Fish. Res. Bd. Can. 25: 579-584.

Wirth, E. F., S. A. Lund, M. H. Fulton, and G. I. Scott. 2002. Reproductive alterations in adult grass shrimp, Palaemonetes pugio, following sublethal, chronic endosulfan exposure. Aquat. Toxicol. 59: 93-99.

Wu, R. S. S., P. K. S. Lam, and K. L. Wan. 2002. Tolerance to, and avoidance of, hypoxia by the penaeid shrimp (Metapenaeus ensis). Environ. Pollut. 118: 351-355.

Yu, B. P. 1994. Cellular defenses against damage from reactive oxygen species. Physiol. Rev. 74: 139-162. 